\title{
Natural Regeneration Under Influence of Sustainable Management Plan in Caatinga
}

\author{
Mailson Pereira de Souza ${ }^{1}$, Allyson Rocha Alves ${ }^{2}$, Ivonete Alves Bakke ${ }^{3}$, Josueldo Alves Lopes ${ }^{4}$, \\ Wellington de Sousa Santos ${ }^{4}$, Emanoel Messias Pereira Fernando ${ }^{5}$, Amanda de Lira Freitas ${ }^{6}$ \\ $\&$ Felipe Silva Amorim ${ }^{7}$ \\ ${ }^{1}$ Postgraduate Program in Environmental and Forest Sciences, Federal Rural University of Rio de Janeiro, \\ Seropédica, RJ, Brazil \\ ${ }^{2}$ Department of Plant Sciences, Federal Rural University of the Semi-Arid, Mossoró, RN, Brazil \\ ${ }^{3}$ Academic Unit of Forest Engineering, Forest Engineer, Federal University of Campina Grande, Patos, PB, \\ Brazil \\ ${ }^{4}$ Graduated in Forestry Engineering, Federal University of Campina Grande, Patos, PB, Brazil \\ ${ }^{5}$ Graduated in Biological Sciences, Federal University of Campina Grande, Patos, PB, Brazil \\ ${ }^{6}$ Department of Forestry Sciences, Postgraduate Program in Forest Sciences, Federal University of Campina \\ Grande, Patos, PB, Brazil \\ ${ }^{7}$ Department of Forest Engineering, Federal University of Piauí, Bom Jeus, PI, Brazil \\ Correspondence: Mailson Pereira de Souza, Federal Rural University of Rio de Janeiro, Seropédica, RJ, Brazil. \\ E-mail: mailsonflorasertao@gmail.com
}

$\begin{array}{lc}\text { Received: February 18, } 2019 & \text { Accepted: May 11, } 2019 \quad \text { Online Published: July 15, } 2019 \\ \text { doi:10.5539/jas.v11n10p194 } & \text { URL: https://doi.org/10.5539/jas.v11n10p194 }\end{array}$

\begin{abstract}
Despite being one of the most heterogeneous Brazilian biomes, regardless of being the least known, the Caatinga is under strong anthropism. In this way the forest management offers techniques that, when used, guarantees the maintenance of the sustainability of the productive system, sustainability that is guaranteed through the resilience of the regenerative stratum. Thus the objective of this work was to evaluate the effect of forest management on natural regeneration in a caatinga area, under different cutting ages. The study was developed in the settlement of the agrarian reform, Brandão III, located in the city of Cuité-PB. To evaluate the natural regeneration, 40 plots measuring $5 \times 5 \mathrm{~m}\left(25 \mathrm{~m}^{2}\right)$ were randomly allocated within the plots exploited and in the Legal Reserve. All individuals with Circumference at baseline $(\mathrm{CNB}) \leq 6 \mathrm{~cm}$ and with a minimum height of $0.5 \mathrm{~m}$ were measured, and distributed in three height classes. A C1: $0.5 \mathrm{~m}<\mathrm{H}<0.99 \mathrm{~m} ; \mathrm{C} 2: 1.0 \mathrm{~m} \leq \mathrm{H}<1.99 \mathrm{~m}$ and $\mathrm{C} 3: \mathrm{H}>2.0 \mathrm{~m}$. The data of density, richness and number of individuals by type of regeneration origin were compared by the Tukey test at $5 \%$ significance. We sampled 2021 individuals, represented by 32 species, 27 genera distributed in 16 families. The exploration did not cause significant changes to the floristic composition nor to the richness of the species. The exploration and the time elapsed between the cut and the measurement influenced the increase of the density.
\end{abstract}

Keywords: diversity, sustainable exploitation, structures

\section{Introduction}

The degradation of the Caatinga biome has been a subject much debated in recent years, as well as strategies and actions aimed at sustainability of the use of natural resources. Holland et al. (2015) have reported that historically the Northeastern man has always sought fertile soils for agricultural and agricultural practice, factors considered one of the main causes that contribute to degradation of the biome, leaving soils exposed and susceptible to erosion. Linked to this culture stands out the unsustainable use of wood resources in detriment of the demand for energy for ceramics, poles, bakeries, and families in the Northeast. Therefore, obtaining information related to the regenerative process is extremely important when the objective is the development of strategies and methods that enable the restoration of the ecological processes that guarantee the sustainability of the productive environment. 
Fundamental natural regeneration study is fundamental for the adoption and achievement of forest management, restoration and conservation plans, and can provide information on the level of ecological stability and speed of recovery of the forest ecosystem. Thus, natural regeneration is important for the maintenance of forest ecosystems, because they provide knowledge of the dynamics of the biomes and for the selection of techniques for the recovery of areas that have suffered some type of impact (Alves Júnior et al., 2013).

It has been verified that the sustainable use of the resources of the Caatinga biome is possible with adequate management methods and techniques, becoming essential knowledge about the dynamics of natural regeneration. For Pereira et al. (2001), one can not consider a rational exploitation of the natural resources of an ecosystem without first knowing the dynamic processes of the same, the responses of natural regeneration to the anthropic disturbances. Lucena, Silva, and Alves (2016) made it clear that the responses offered by natural regeneration in relation to impacts generate information that helps in the adoption of actions that aim at the adoption of techniques and methods that assure the productive sustainability of a given ecosystem. Thus, the answers make it possible to know the possibility of compromising the regeneration capacity of vegetation resources in caatinga environments.

Based on the above, the present study seeks to answer the following questions: does the exploitation of the caatinga vegetation through the sustainable management plan compromise or negatively affect the floristic and structural composition of natural regeneration? What is the influence of managed exploration time on natural regeneration? The objective of this study was to evaluate the natural regeneration in an area of managed caatinga, under different cutting ages, in order to offer technical subsidies to the actions aimed at the sustainability and recovery of this ecosystem.

\section{Material and Methods}

\subsection{Characterization of Areas and Data Collection}

The research area is located about $20 \mathrm{~km}$ from the city of Cuité, between coordinates $06^{\circ} 27^{\prime} 36^{\prime \prime} \mathrm{S}$ and $36^{\circ} 02^{\prime} 54^{\prime}$ $\mathrm{W}$, with approximately 1,384 hectares, $50 \%$ of which are destined for sustainable forest management. The municipality of Cuité belongs to the do Planalto da Borborema Eco-region, with altitudes varying between 650 and 1000 meters. It is marked by the strong presence of relief, mostly wavy, receiving prominence some deep and dissected narrow valleys. It has soils with fertility that varies from medium to high (CPRM/PRODEEM, 2005). According to Alvares et al. (2014), the climate of the region is classified by Bsh, semi-arid hot, with average annual rainfall of $600 \mathrm{~mm}$. year ${ }^{-1}$ and average temperatures of $30^{\circ} \mathrm{C}$.

The soils of the property present an association noted in the whole of the analogous region, being classified according to the analysis of the Exploratory Map-Soil Recognition of the State of Paraíba, 1971 (Jacomine et al., 1972): an association of type Neosolo Litólico, sandy texture and/or medium stony phase and Red-Yellow Distropic Argissol (Santos et al. 2013).

The Brandão III property presents an exuberant vegetation of the Type 4 Hyperxerophilic Caatinga-Closed Arboreal Vegetation (SUDEMA, 2004), formed by a dense, dominant woody vegetation with a size varying between 6 and 10 meters, with an estimated timber stock for the Borborema mesoderm, at 205.09 st/ha (Silva, 1994).

The four areas chosen for the study development are included in the sustainable management plan. The first area is related to the Legal Reserve with approximately 276.93 ha, the second is the UPA 04 corresponding to the annual production unit explored in 2007, with approximately 27.9 ha. The third area was UPA 13, with an approximate area of 27.3 ha, designated UPA 2012 and the fourth area was UPA 02, denominated UPA 2014, whose exploration took place in the year 2014 with about $29.2 \mathrm{ha}$.

In order to evaluate the natural regeneration, 10 random plots of $5 \times 5 \mathrm{~m}\left(25 \mathrm{~m}^{2}\right)$ were installed within the UPA's and the Legal Reserve (R.L.). The individuals with CNB $\leq 6 \mathrm{~cm}$ and with a minimum height of $0.5 \mathrm{~m}$ were measured. These inclusion criteria served as counting parameters, counting the plants that met the proposed requirements (RMFC, 2005). It is important to note that in the case of several shoots per strain, all were counted as one individual separately. This methodology was adapted from the norms for the sampling of regenerating individuals of the Forest Management Network of the Caatinga, where all the branches bifurcated before $30 \mathrm{~cm}$ of the soil are considered individuals separately.

Regarding the origin of the regeneration, the individuals were grouped to determine if they came from seed germination or from regrowth of strains. Tree regrowth was considered as a regrowth in which the vegetative structure branched out from strains; when not, it was considered seed germination or root regrowth. For these 
individuals the species and height classes were recorded: $\mathrm{C} 1: 0.5 \mathrm{~m}<\mathrm{H}<0.99 \mathrm{~m} ; \mathrm{C} 2: 1.0 \mathrm{~m} \leq \mathrm{H}<1.99 \mathrm{~m}$ and C3: $\mathrm{H}>2.0 \mathrm{~m}$ with $\mathrm{CNB}$ up to $6.0 \mathrm{~cm}$.

The individuals measured were identified in the place with common name, and then when possible collected fertile material for further identification in the CSTR herbarium. The classification system adopted was that of Chase et al. (2009) called Angiosperm Phylogeny Group (A.P.G.III, 2009). The spelling of scientific names and species classifiers was updated according to the List of Brazilian Flora Species 2020 (Forzza et al., 2018).

\subsection{Parameters for Natural Regeneration}

For each species, the absolute and relative frequency and density parameters were estimated for each class of pre-established height. After calculating the density and frequency (relative and absolute) of each height class, for each species, natural regeneration was estimated, given by the formula of Volpato (1994) modified by Silva et al. (2007) (Equation 1).

$$
\mathrm{RNC}_{\mathrm{ij}}=\frac{\mathrm{DR}_{\mathrm{ij}}+\mathrm{FR}_{\mathrm{ij}}}{2}
$$

Where, $\mathrm{RNC}_{\mathrm{ij}}=$ estimate of the natural regeneration of the $\mathrm{i}^{\text {th }}$ species in the $\mathrm{j}^{\text {th }}$ plant height class, in percent; $\mathrm{DR}_{\mathrm{ij}}$ $=$ relative density for the $\mathrm{i}^{\text {th }}$ species in the $\mathrm{j}^{\text {th }}$ natural regeneration height class; $\mathrm{FR}_{\mathrm{ij}}=$ relative frequency of $\mathrm{i}^{\text {th }}$ species, in percent, in the $j^{\text {th }}$ class of natural regeneration.

After calculating the regeneration index by height class for species, the total natural regeneration per species was estimated within the previously established height classes (H). The total natural regeneration (RNT) was calculated by the formula of Volpato (1994) modified by Silva et al. (2007) (Equation 2).

$$
\mathrm{RNT}_{\mathrm{i}}=\sum\left(\mathrm{RNC}_{\mathrm{ij}}\right) / 3
$$

Where, $\mathrm{RNT}_{\mathrm{i}}=$ estimate of the total natural regeneration of the sampled population of the $\mathrm{i}^{\text {th }}$ species; $\mathrm{RNC}_{\mathrm{ij}}=$ estimate of the natural regeneration of the $\mathrm{i}^{\text {th }}$ species in the $\mathrm{j}^{\text {th }}$ plant height class.

\subsection{Floristic Diversity Indexes}

The richness and abundance of the species in each area were evaluated using the Shannon-Wiener Diversity Index $\left(\mathrm{H}^{\prime}\right)$ and Simpson's Index of Dominance $(\mathrm{C})$. The distribution of individuals among the species was studied by the Pielou Uniformity Index (J) and for the analysis of floristic similarity, the Sorensen Similarity Index (Magurran, 1989; Felfili \& Venturoli, 2000; Matteucci \& Colma, 1982) by Cordeiro (2005). Analyzes were performed using the software (Nativa, 2011).

\subsection{Data Analysis and Experimental Design}

Considering each annual production unit (UPA2007, UPA2012, UPA2014 AND Legal reserve) as a treatment and each sample of $25 \mathrm{~m}^{2}$ as a repetition, the prepositions of normality and homoscedasticity were checked and, when possible, the analysis was performed through analysis of variance ( $\mathrm{F}$ test) and comparison of means by the Tukey test for the variables, number of individuals, species richness and number of individuals from the different types of regeneration. Analyzes were performed using the statistical package ASSISTAT Version 7.7 beta (Silva, 2017), at a significance level of 5\%.

\section{Results and Discussion}

\subsection{Floristics}

The sampling adequacy, shown by the Figure 1 collector curve, for the three annual production units (UPA's) and for the Legal Reserve shows that, in general, all the experimental units stabilized from the eighth sampling unit, being highlighted. From that moment onwards, there was a reduction in the number of new species occurring in the experimental units, that is, at $200 \mathrm{~m}^{2}, 100 \%$ of the number of the inventoried species had already been registered. Then there was a stagnation in the number of species, indicating that the sampling performed for the study area was satisfactory, in order to reach the minimum of plots to be used to characterize the floristic composition in the production units. 


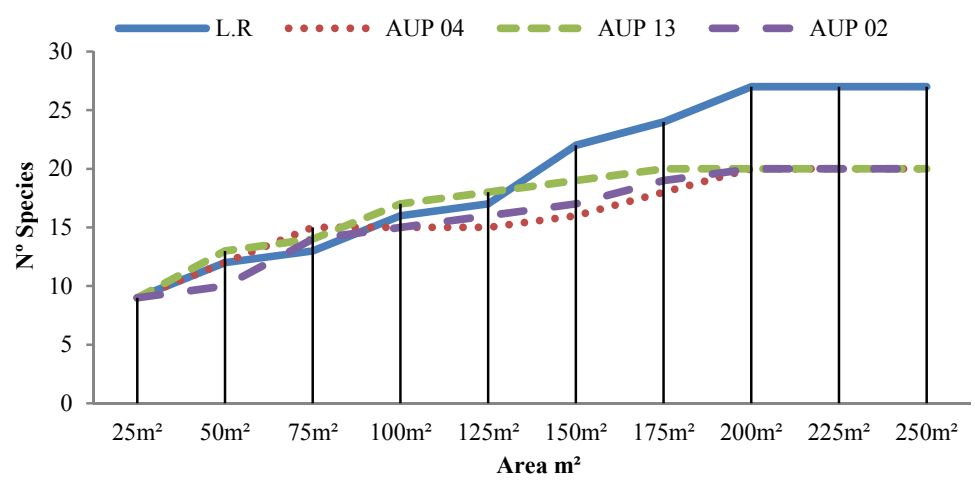

Figure 1. Graphical representation of sample sufficiency in the units of annual production (UAPs) and Legal Reserve in an area submitted to a sustainable management plan, in the city of Cuité-PB

In the 40 units surveyed throughout the area, 2021 individuals were sampled, represented by 32 species, 27 genera and distributed in 16 families (Table 1). In the UPA 0420 species were found distributed in 10 families, in the UPA 13 were present 20 species distributed in 10 families, in the UPA 02 were cataloged 19 species distributed in 8 families, already in the Legal Reserve 27 species were present being these distributed in 16 families.

Table 1. Floristic list present in the 40 plots of the forest inventory in an area under management in Cuité-PB

\begin{tabular}{|c|c|c|c|c|c|c|}
\hline Family & Scientific name & Common Name & AUP04 & AUP13 & AUP02 & L.R. \\
\hline \multirow{2}{*}{ Anacardiaceae } & Myracrodruon urundeuva Allemao & Aroeira & $\mathrm{X}$ & $\mathrm{X}$ & $\mathrm{X}$ & $\mathrm{X}$ \\
\hline & Spondias tuberosa Arruda & Umbu & - & - & - & $\mathrm{X}$ \\
\hline Apocynaceae & Aspidosperma pyrifolium Mart. \& Zucc. & Pereiro & $X$ & $X$ & $X$ & $\mathrm{X}$ \\
\hline Bignoniaceae & Handroanthus impetiginosus (Mart. ex DC.). Mattos & Ipê Roxo & $X$ & - & - & - \\
\hline Capparaceae & Cynophalla flexuosa (L.) J.Presl & Feijoão bravo & - & $x$ & $X$ & $\mathrm{X}$ \\
\hline Burseraceae & Commiphora leptophloeos (Mart.) J.B.Gillett & Imburana de Cheiro & - & - & - & $\mathrm{X}$ \\
\hline Capparaceae & Neocalyptrocalyx longifolium (Mart.) Cornejo \& Iltis & Icó & - & $X$ & - & $\mathrm{X}$ \\
\hline Combretaceae & Combretum laxum Jacq. & Bugi & $X$ & - & $X$ & $\mathrm{X}$ \\
\hline \multirow{3}{*}{ Erythroxylaceae } & Erythroxylum pauferrense Plowman & Coração de Negro & - & - & - & $\mathrm{X}$ \\
\hline & Sapium glandulosum (L.) Morong & Burra leiteira & $\mathrm{X}$ & - & - & $\bar{X}$ \\
\hline & Manihot glaziovii Müll.Arg. & Maniçoba & $\mathrm{X}$ & - & $\mathrm{X}$ & $\mathrm{X}$ \\
\hline \multirow[t]{7}{*}{ Euphorbiaceae } & Croton blanchetianus Baill & Marmeleiro & $\mathrm{X}$ & $\mathrm{X}$ & $\mathrm{X}$ & $\mathrm{X}$ \\
\hline & Sebastiania sp. & Pau de leite & $\mathrm{X}$ & $\mathrm{X}$ & $\mathrm{X}$ & $\mathrm{X}$ \\
\hline & Jatropha mollissima (Pohl) Baill. & Pião manso & $\mathrm{X}$ & $\mathrm{X}$ & - & $\mathrm{X}$ \\
\hline & Mimosa ophthalmocentra Mart. ex Benth.cf & Amorosa & $X$ & $X$ & $\mathrm{X}$ & $\mathrm{X}$ \\
\hline & Anadenanthera colubrina (Vell.). Brenan & Angico & $\mathrm{X}$ & $\mathrm{X}$ & $\mathrm{X}$ & $\mathrm{X}$ \\
\hline & Senna macranthera (DC. ex Collad.) H.S.Irwin \& Barneby & Canafistula mirim & $\mathrm{X}$ & $\mathrm{X}$ & $\mathrm{X}$ & $\mathrm{X}$ \\
\hline & Poincianella pyramidalis (Tul.) L. P. Queiroz & Catingueira & $\mathrm{X}$ & $\mathrm{X}$ & $\mathrm{X}$ & $\mathrm{X}$ \\
\hline \multirow[t]{5}{*}{ Fabaceae } & Piptadenia stipulacea (Benth.) Ducke & Jurema branca & $\mathrm{X}$ & $\mathrm{X}$ & $\mathrm{X}$ & $\mathrm{X}$ \\
\hline & Mimosa tenuiflora (Willd.) Poir. & Jurema preta & $\mathrm{X}$ & $\mathrm{X}$ & $\mathrm{X}$ & $\mathrm{X}$ \\
\hline & Cronton sp. & Marmeleiro branco & - & $\mathrm{X}$ & - & $\mathrm{X}$ \\
\hline & Bauhinia cheilantha (Bong.) D. Dietr. & Mororó & $\mathrm{X}$ & $\mathrm{X}$ & $\mathrm{X}$ & $\mathrm{X}$ \\
\hline & Amburana cearenses (Allemão) A.C.Sm. & cumaru & - & - & - & $\mathrm{X}$ \\
\hline Malvaceae & Pseudobombax marginatum (A.St.-Hil., Juss. \& Cambess.) A.Robyns & Embiratanha & & $X$ & & $\mathrm{X}$ \\
\hline Myrtaceae & Eugenia uvalha Cambess. & Baia & - & $X$ & - & $\mathrm{X}$ \\
\hline Nyctaginaceae & Guapira graciliflora (Mart. ex Schmidt) Lundell & João mole & $X$ & $X$ & - & - \\
\hline Olacaceae & Ximenia americana $\mathrm{L}$. & Ameixa & $\mathrm{X}$ & - & $X$ & $\mathrm{X}$ \\
\hline Rhamnaceae & Ziziphus joazeiro Mart. & Juazeiro & $\mathrm{X}$ & - & - & $\mathrm{X}$ \\
\hline \multirow[t]{2}{*}{ Sapotaceae } & Sideroxylon obtusifolium (Roem. \& Schult.) T.D. Penn. & Quixabeira & - & - & - & $\bar{X}$ \\
\hline & Morphospecies & Mapirunga & - & $X$ & - & - \\
\hline \multirow[t]{2}{*}{ Undetermined } & Morphospecies & Quebra faca & - & - & $\mathrm{X}$ & - \\
\hline & Morphospecies & Rompi gibão & $\mathrm{X}$ & - & - & $\mathrm{X}$ \\
\hline
\end{tabular}


The numbers of species and families found in these areas were higher than those of other Caatinga studies. Alves et al. (2010) found 13 species and 7 families, in a fragment of Caatinga free of anthropic action accentuated 32 years ago, in the municipality of Pombal-PB. Alves Junior et al. (2013) studying the natural regeneration of a Caatinga area in the Sertão of Pernambuco found 15 species distributed in 7 families. Lucena, Alves, and Silva (2016) evaluating the natural regeneration of the shrub-arboreal stratum in two areas of Caatinga managed on two different occasions recorded values in Esec do Seridó, in 2009 of 12 species, 10 genera and 7 botanical families, for the year 2011 was found 11 species, 9 genera and 7 families. At the Fazenda Pedro Cândido, in 2011, we observed 8 species, 8 genera and 5 families.

Similar results were reported by Almeida (2014), who analyzed adult and regenerating individuals in the same area in three experimental units, where 30 species distributed in 15 families were found. In UPA 04, 23 species belonging to 12 families in PAU 13, 16 species distributed in 8 families, and in R.L., 23 species, representing 12 families. Silva et al. (2012), evaluating the natural regeneration in a Caatinga remnant with different use histories in Pernambuco, where one area had no history of intensive soil use and the other was in a recovery process at 30 years, found 17 botanical families, 26 genera and 30 species. Seventeen botanical families were registered, 21 genera and 26 species, and three unidentified individuals in Area I and 14 botanical families, 19 genera and 23 species, and three unidentified individuals in Area II.

Andrade-Lima (1981) states that the caatingas located in places where the precipitations are more accentuated present a greater number of species, being this factor often limiting when the subject is floristic diversity. Thus higher values of diversity may be related to the pluviometric issue of the different regions. However, Rodal, Martins, and Sampaio (2008) reported that not only the total rainfall can modify the quantity of species and individuals, that is, other elements should be considered, topographic condition, class, depth and soil permeability.

The families that presented the greatest number of species were: Fabaceae with 8 species, Euphorbiaceae with 6 species and Anacardiaceae with 2 species, the other families added had 16 species. These three families had $50 \%$ of the total number of species, and the other half $(50 \%)$ of the families were represented by only one species. For Alves Júnior (2013) the families Euphorbiaceae, Anacardiaceae and Fabaceae present the majority of the species of the caatinga areas. In addition, they have also been reported as having the highest number of species in other studies on natural regeneration (Holand et al., 2015; Lucena, Alves, \& Silava, 2016, Lucena, Alves, \& Bakke, 2017).

\subsection{Structure}

The total densities found for this study were $13,680,19,520,20,760$ and 26,880 ind. ha ${ }^{-1}$ for the experimental units, Legal Reserve, UPA 04, UPA 13 and UPA 02, respectively. The superiority of the values presented here is probably due to the methodology adopted as inclusion criterion for the regenerating individuals, where all the shoots of the same stump were considered as different individuals. This is most evident in UPA 02, whose value was considerably higher than those observed in the other experimental units.

The values were higher than those found by Alves et al. (2010) that when estimating the natural regeneration at Fazenda São João in the city of Pombal-PB, found an absolute density of 4,272 ind. ha ${ }^{-1}$. It also presented superiority to the study by Silva et al. (2012), which evaluated the natural regeneration in a caatinga remnant with different use histories in the Pernambuco hinterland, observed values of 11,200 ind. ha ${ }^{-1}$ and 8,116 ind. ha ${ }^{-1}$ in Areas I and II, respectively.

It was found that the larger the time elapsed between the time of the exploration and the smaller the number of individuals per area sampled. The highest number observed for UPA 02 shows the physiological response of vegetation to the exploration. According to Sampaio et al. (1998), the cut in Caatinga species has a direct effect on physiological processes, thus inducing intense meristematic activity in large parts of the plants for the regeneration of the aerial system, with the accumulation of accumulated reserves in the subterranean systems and in the stem stumps. In contrast, the lower value observed for UPA 04 reinforces the justification of competition among regenerating individuals over time, contributing to a decrease in the number of individuals.

The decrease in the number of individuals over time is expected due to the various competition processes that control the successional dynamics, so the results presented here corroborate with Lucena, Silva, and Alves (2016) who observed the decrease in the number of individuals of an occasion of monitoring to another. The authors pointed out that this loss can be attributed not only to competition between individuals, but also to several factors, among which precipitation becomes the main control agent of natural regeneration. This last factor is the major limiting factor for crop production in the semiarid region, where rainfall is irregular both temporal and spatial. 
Based on the disturbance caused by the vegetation cut, and the time elapsed from the farm to the measurement, as well as their influence on the density of the individuals (342 ind. 488 ind., 519 ind. and 672 ind.), it was observed that statistically factors did not cause a difference between the three UPAs at 5\% significance (Figure 2). However, it was observed that UPA 02 was statistically different from R.L, where there was no intervention, this reinforces the hypothesis that the managed exploration positively influenced the increase in the number of individuals, with an increase in the number of individuals of all areas explored in relation to R.L.

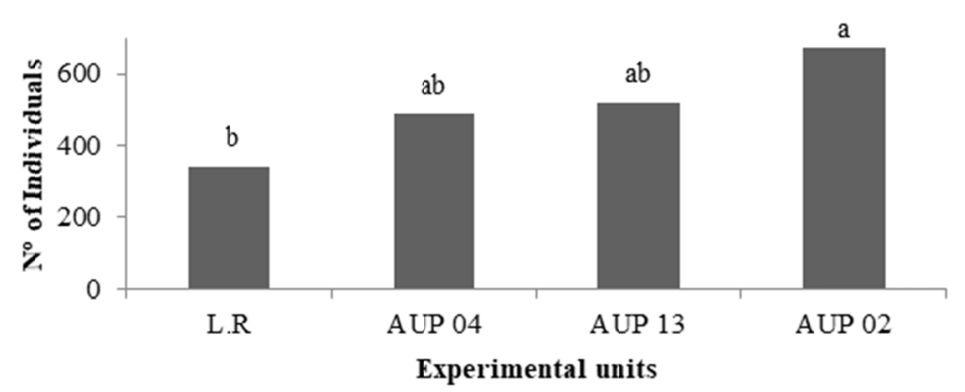

Figure 2. Managed exploitation and time influence in the number of individuals and its statistic difference between experimental units in an area under a sustainable management plan in Ciuité-PB

Simultaneously analyzed the factors exploitation and time spent between exploration and measurement, an increase in observed density was observed. In this way it is possible to perceive that the smaller the interval of time covered the greater the amount of regenerating individuals. For Silva et al. (2012), the higher density caused by the exploitation, is due to the spaces and clearings that aid in the increase of germination, thus promoting higher densities of regenerants. In addition, the physiological response of the plants to the exploitation (regrowth) directly influences this increase.

It is important to highlight the values obtained for the species Croton blanchetianus and Poincianella pyramidalis, the same ones stand out in relation to the others, a similar behavior of these species is observed among the UPAs, being those that have higher values of TNF in UPA 04, UPA 13 and UPA 02 (Figure 3). Several authors point out that this behavior is expected for disturbed environments since the pioneer species, in which the species treated here are the main responsible for the colonization of disturbed environments (Pereira et al., 2014).

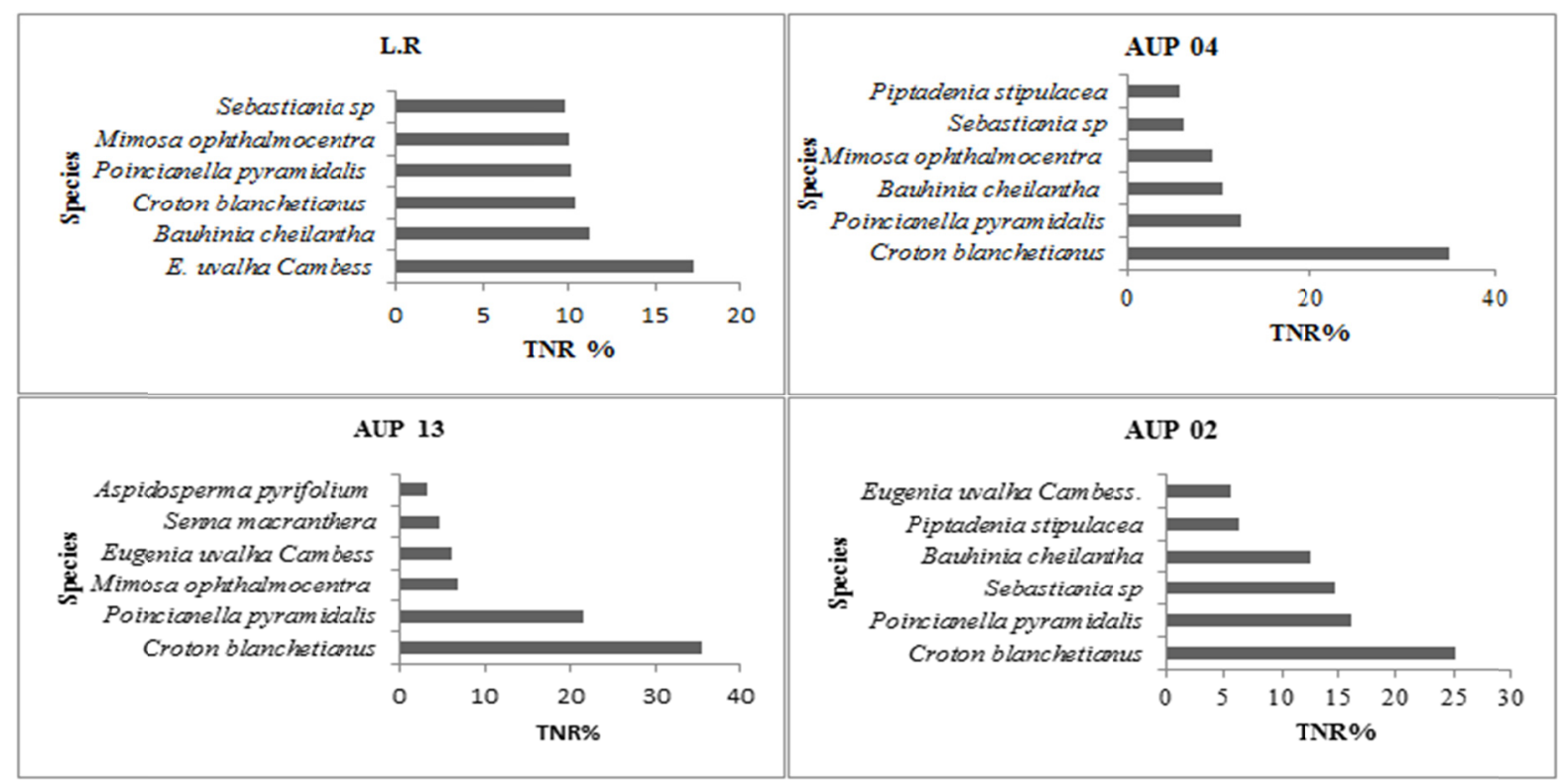

Figure 3. Percentual values of Total Natural Regeneration (TNR) of the six principal arboreous/shrubby species in an area under sustainable management plan in Cuité-PB 
Several studies have highlighted Croton blanchetianus as being one of the main species in natural regeneration, due to the fact that it has a very easy seed dispersion, thus contributing to enrichment of the soil seed bank, dominating the first serous stages (Alves et al., 2006). Pereira et al. (2001) pointed out that this behavior is verified in other pioneer species typical of anthropic Caatinga environments, such as Poincianella pyramidalis, Bauhinia cheilantha and Piptadenia stipulacea.

Regarding the height classes of the 342 living individuals sampled in the Legal Reserve, $31.57 \%$ are present in class I; $41.52 \%$ are present in class II and $26.91 \%$ in class III. In the UPA 04 of the 488 living individuals sampled, $31.14 \%$ are present in class I, $44.87 \%$ are present in class II and $23.99 \%$ in class II. For UPA 13 a total of 519 living individuals were sampled, and $34.84 \%$ were present in class I; $52.21 \%$ were in class II and 67 individuals were present in class III. In UPA 02, it was observed that of the total of 672 living individuals, $41.51 \%$ were in class I; $54.61 \%$ were present in class II and 3.88\% individuals were present in the last class (Figure 4).

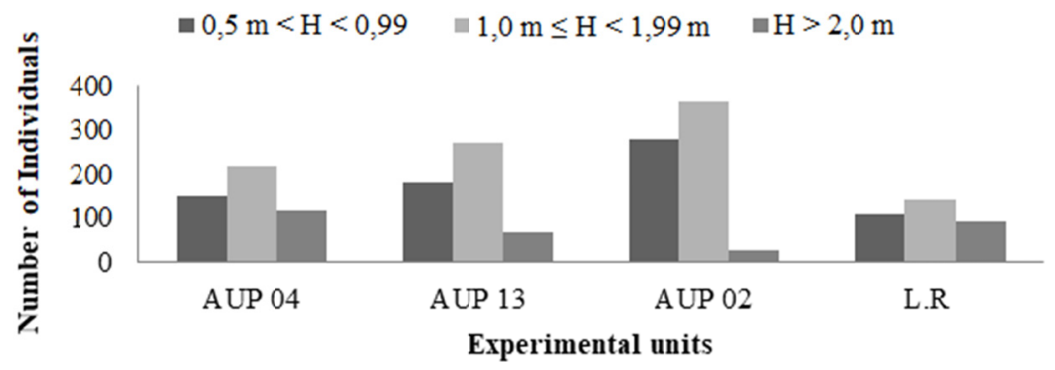

Figure 4. Number of individuals distributed within the three height classes in the experimental units in an area under the sustainable management plan in Cuité-PB

The managed exploration and the state of conservation of the units directly influence the distribution of individuals by height class. Thus, the shorter the time elapsed between the exploration and the occasion of monitoring (a short time of recovery of regenerating individuals), the higher the number of individuals present in the first class. Class II presented the highest number of individuals for all experimental units, which can be justified by the inclusion of a larger number of individuals in this class. The lowest number of individuals observed in class III probably occurs due to intraspecific and interspecific competition between species (Holland et al., 2015). The authors found that these factors are most often responsible for the decrease in the number of individuals of a given height class. The lower number of individuals in class I compared to class II can be explained by being more susceptible to mortality and by the transition of some individuals to the next class (Alves Júnior et al., 2013; Lucena, Silva, \& Alves, 2016).

Of the 27 species sampled in the Legal Reserve, 11 (40.74\%) were present in all height classes, $9(33.33 \%)$ were found in only two height classes, while $7(25.93 \%)$ were only in one height class. In the UPA 04 of the 20 species found $10(50 \%)$ occupied all height classes, $5(25 \%)$ species were present in only two classes and $5(25 \%)$ species occupied only one class, the distribution of species in classes of height in UPA 13 followed the same pattern as UPA 04. However UPA 02 of 19 species, 5 (26.28\%) were present in all height classes, $7(36.86 \%)$ species were found in two classes and $7(36.86 \%)$ species occurred only in one height class.

Theoretically, the species present in all classes of heights are the ones that have the greatest chances and potential to be part of the future floristic composition of the forest, that is, those that are best established in biocenosis. According to Rêgo (2007), the occurrence of species in only two classes of heights is due to the existence of natural and/or anthropic disturbances, which create highly heterogeneous habitats in the forest environment, providing the recruitment of different species of plants, exhibiting different regeneration scenarios. This can be observed with normality in environments disturbed by vegetation cutting, as is the case with UPA's.

Regarding the type of origin of the regenerating individuals sampled in the experimental units, it is observed that the vegetation cut tends to interfere in the predominant regeneration in the area. A total of 509 individuals originating from regrowth of strains were found to be dominated by regrowth in UPA 02 (area with more recent cut), while 163 individuals originated from seeds or root shoots. The Legal Reserve exempt from any exploration had a total of 37 individuals from regrowth and 305 individuals from seeds/roots. For the other experimental units, there was a greater number of regeneration from regrowth, the percentage of this relationship is explicit in (Figure 5). 


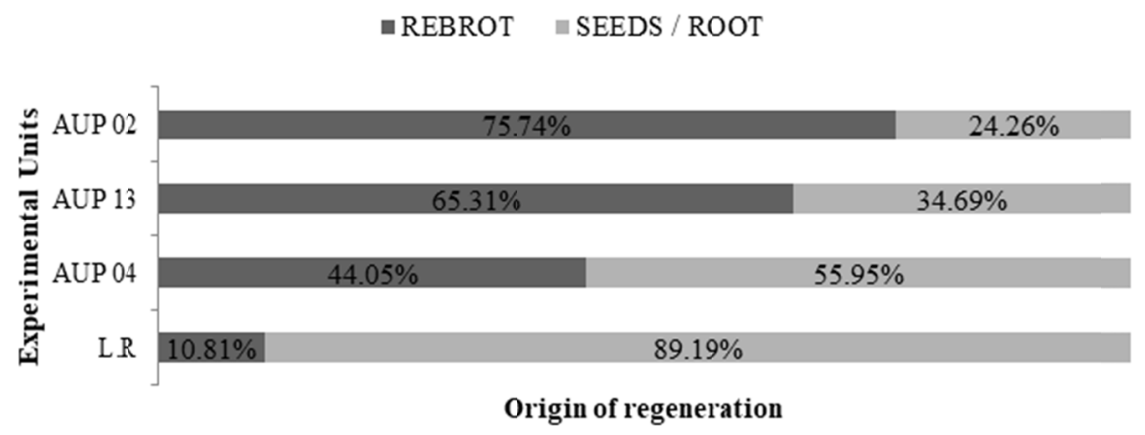

Figure 5. Percentage of individual number distribution by type of origin of regeneration in an area under a sustainable management plan in Cuité-PB

The results clearly demonstrate the influence that the disturbance on the vegetation causes the recovery of the individuals, especially in the natural regeneration of a forest fragment. It is possible to observe that the more recent the exploitation the greater the percentage of individuals originated from shoots than those from seed/root, and that with the passage of time this proportion tends to balance even in an area under management.

Alves et al. (2010), studying an area that was deforested in 1976 and 1977 for cotton cultivation, which gave rise to cattle grazing and removal of wood, found that, despite the anthropic action and presence of cattle in the study area, The fragment presented progression in the successional process, and this was the result of plant regeneration, since $80 \%$ of the total individuals are from seeds, while the rest comes from regeneration by regrowth of strains. Although sprout contributes to a rapid regeneration of anthropic areas, seed germination is a strategy of great importance for the recovery of areas of dry environments, however, factors that compromise rainfall or survival of seeds in the soil end up exerting a strong influence on the regeneration of areas that have undergone human intervention.

The values obtained for this work corroborate those found by Almeida (2014), emphasizing that vegetation tends to regenerate positively in the study areas, being thus directly influenced by environmental conditions, correlated with applied techniques in sustainable forest management, such as cutting only individuals with CAP $>6 \mathrm{~cm}$, maintenance of seed and legally protected trees, maintenance of soil debris in the soil and prohibition of fires, thus creating adequate conditions for the emergence of new individuals for most of the species present in the studied area.

When applying the Tukey test to $5 \%$ of significance for the different totals of individuals from the different types of regeneration, it was verified that the UPA 02 in relation to regeneration from regrowth was statistically different from UPA 04 and the Legal Reserve, the Legal Reserve differed from UPA 13 and UPA 02 (Figure 6).

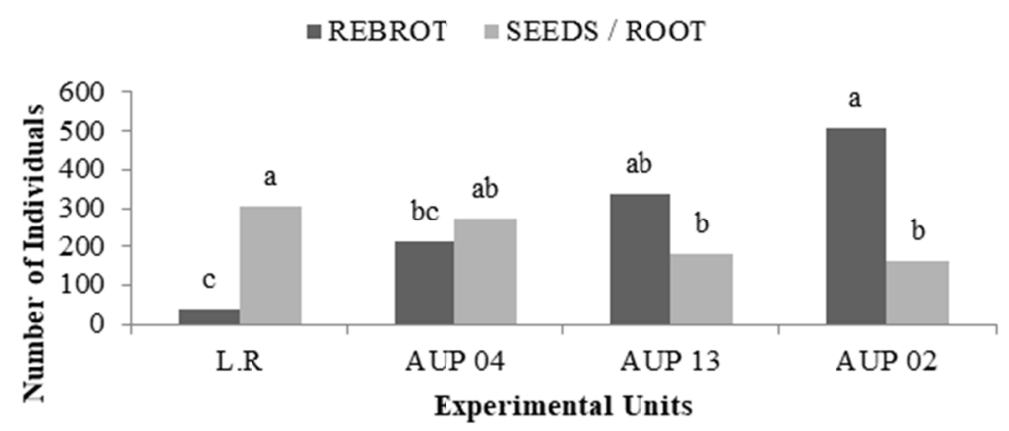

Figure 6. Number of individuals and origin of natural regeneration in respective experimental units in an area under a sustainable management plan in Cuité-PB

Probably the values observed for individuals from seeds/roots are related to the low rainfall indexes registered in the municipality where the research area is located, since these seeds deposited in the soil seed bank need water to enable their physiological processes so that they will emerge and remain stable in the environment. 


\subsection{Flower Diversity}

Considering the Shannon-Weaver Diversity Index (H'), it was found that the greatest diversity of species was

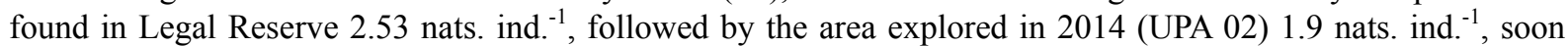
after area explored in 2007 (UPA 04) presented a value of 1.87 nats. ind. ${ }^{-1}$, already the area explored in 2012 (UPA 13) had a value of 1.71 nats. ind. ${ }^{-1}$ which can be easily evidenced in (Table 2).

Table 2. Indexes-Shannon-Wiener's Diversity Index (H'), Simpson's (C'), Pielou's Equability Index (J') and the number of species (S) between the four experimental units studied areas in an area under sustainable management plan in Cuité-PB

\begin{tabular}{lllll}
\hline Indexes & L.R. & AUP 04 & AUP 13 & AUP 02 \\
\hline H' & 2.53 & 1.87 & 1.71 & 1.96 \\
J & 0.77 & 0.62 & 0.57 & 0.65 \\
C & 0.88 & 0.73 & 0.68 & 0.79 \\
S & 27 & 20 & 20 & 19 \\
\hline
\end{tabular}

The results were generally higher than those found by Alves et al. (2010), in Caatinga with low anthropization, in the municipality of Pombal (PB), whose value was 0.84 nats. ind. ${ }^{-1}$, to those verified by Holanda et al. (2015), which studied the Structure of the vegetation in remnants of caatinga with different disturbance histories in Cajazeirinhas (PB), found values of 0.80 nats. ind.$^{-1}$ and 1.21 nats. ind. ${ }^{-1}$, corresponding to two environments in different stages of degradation. When comparing with the values found by Lucena, Alves, Silva (2016) only the value of the Legal Reserve presented superiority to the previously specified study, the authors studying the natural regeneration in two caatinga areas at the Seridó Ecological Station on two occasions observed values of 1.63 nats. ind ${ }^{-1}, 0.99$ nats. ind. ${ }^{-1}$ for 2009 and 1.71 nats. ind. ${ }^{-1}, 1.12$ nats. ind. ${ }^{-1}$ for the year 2011.

Almeida (2014) studying adult and regenerating individuals in the same area found values similar to those observed for this occasion. For the Legal Reserve the value was 2.24 nats. ind. ${ }^{-1}$, the UPA 04 presented value of 1.70 nats. ind. ${ }^{-1}$ and the UPA 13 had a value of 1.33 nats. ind. ${ }^{-1}$. When analyzing the value it is noticed that the area is recovering. However, it is observed that the number of species occurring between the two studies, in the Legal Reserve and in the UPA 13 there was an increase, in the UPA 04 the number decreased. Possibly, the reason for the greatest diversity in the year 2017, even in spite of the smaller number of species in some experimental units, is due to the more equitable distribution of the number of individuals among the observed species.

When these values are compared to each other, it is observed that the Legal Reserve, because it did not suffer any type of disturbance, has a higher value than the other experimental units, since this experimental unit had a state of preservation much better than the other areas. Although the exploitation carried out in the vegetation creates new environments that are often favorable to the invasion of opportunistic or shade tolerant species, it is generally found that the exploitation negatively affects the diversity of the forest fragment managed. However, this exploitation, because it is managed and sustainable, favors the recovery of the regenerating individuals in an effective way, this thesis is confirmed when comparing the present study with the others carried out in environments of disturbed caatinga or even under silvicultural treatments.

For Scolforo and Carvalho (2008), small values of (H') characterize a possible reduction of diversity, and another cause of great variability of species richness is also the anthropization to which part of the areas is submitted. However, Santana and Souto (2006) affirm that the comparison of different areas by means of diversity indexes should be carried out in a cautious way from several perspectives, since the indices are strongly influenced by both biotic and abiotic factors, inclusion criteria, beyond the time of anthropism. Almeida (2014) emphasizes that although in the Caatinga there are several phytophysiognomies present, and when analyzed with different sampling processes and inclusion levels from one work to another, these factors favor variations in diversity values, however, this index is considered a great factor for species richness analysis.

In relation to the Pielou index, the variation between the values presented for the experimental units (Table 2) is indicative of a relative homogeneity in the distribution of the species in the plots, even with the high concentration of $C$. blanchetianus individuals. The value of equability found in the present study was similar to those diagnosed in several areas of Caatinga biome occurrence, highlighting the surveys made by Marangon et al. (2013), Ferraz et al. (2014), and Santos et al. (2017) who found values between 0.50 and 0.73. Based on the assumption that the values presented in the experimental units are similar to those of some areas that do not show 
signs of anthropization, Almeida (2014) stated that the maintenance of these values is probably allied to the fact that the exploration occurs in a managed way, greater diversity when vegetation has been in use for some time.

As regards the Simpson Diversity Index (C), it can be observed that there is similar diversity among the three areas. The values ranged from 0.68 to 0.88 , the lowest being UPA 13 and the highest as expected in relation to the Legal Reserve. This fact is probably related to the organized exploration, which according to studies developed by Almeida (2014) and the present work, the data indicates that the management does not present negative effects on the regeneration of the species.

The Søresen Similarity index allowed us to verify that the four areas presented similarities among themselves regarding the composition of species (Table 3).

Table 3. Søresen's Similarity Index among the four studied areas in an area under the sustainable management plan in Cuité-PB

\begin{tabular}{lllllll}
\hline & AUP04/AUP13 & AUP04/AUP02 & AUP04/LR & AUP13/AUP02 & AUP13/LR & AUP02/LR \\
\hline SO & 0.65 & 0.82 & 0.72 & 0.77 & 0.77 & 0.74 \\
\hline
\end{tabular}

In general, it is observed that there is a high similarity between the experimental units studied, since values above $50 \%$ have a high similarity (Sabino, Cunha, \& Santana, 2016). This fact probably occurs due to the proximity of the studied areas, facilitating that the factors responsible for the formation of the floristic composition act in all the experimental units.

The sustainable forest management in the area did not significantly affect the number of species occurring in the experimental units. Based on the results presented here, it can be observed that the number of species found was reduced by comparing the Legal Reserve (unit that was not cut) and the other exploration units (Table 2). Even occurring this decrease in the number of species it is emphasized that managed exploration is a strategy that ensures the floristic richness, considering that when compared the number of species found in the units under management with surveys of regenerating individuals in an unsustainably exploited area and areas with a long fallow and recovery period, a great difference is observed in relation to the total number of species (Alves et al., 2010; Alves Júnior et al., 2013; Holanda et al., 2015). Also to be considered is that when applying the Tukey test to $5 \%$ of significance, the experimental units did not present significant difference between them.

Currently the sustainability of the sustainable management plan in the Caatinga has been a much debated topic, groups of researchers have taken opposing positions on this theme. Both sides are keenly defended by their components, each analyzing the different points of view, whether they are productive or ecological. In this way it is necessary to emphasize that the conclusions evidenced herein are directly related to the environmental conditions, whose area studied is submitted.

Thus, the authors reinforce and advise that other works with the same purpose should be carried out in different places so that the actions and strategies directed to areas under forest management will be more accurate and safe, since the biome presents high heterogeneity in the edaphoclimatic relationships and can cause different results in the structure and composition of the regenerating community. Thus, other methodologies for monitoring the development of regenerating individuals should be tested, since in the mentioned work the plots did not have a permanent evaluation in space or in time.

\section{Conclusions}

The Management Plan developed at the Annual Production Units (PAUs) favored their maintenance until the present study.

The exploration and the time elapsed between the cut and the measurement influenced the increase of the density.

The exploitation did not affect the floristic richness of the managed area, despite the decrease in the number of species between the Legal Reserve and the UPA's, maintaining floristic similarity among the studied areas.

Cutting vegetation tends to interfere with the predominant type of regeneration in the area. The longer the time between the exploration and the smaller the number of individuals from sprout shoots will be.

\section{Acknowledgements}

This study was financed in part by the Coordenação de Aperfeiçoamento de Pessoal de Nível Superior-Brasil (CAPES)-Finance Code 001. 


\section{References}

Almeida, F. C. P. (2014). Estrutura e regeneração natural em remanescentes de caatinga sob manejo florestal, Cuité-PB (Dissertação de Mestrado em Ciências Florestais, Universidade Federal de Campina Grande, Patos, Paraíba).

Alvares, C. A., Tape, J. L., Sentelhas, P. C., Gonçalves, J. L. M., \& Gerd Sparovek, G. (2014). Köppen’s climate classification map for Brazil. Meteorologische Zeit, 22(6), 711-728. https://doi.org/10.1127/0941-2948/ 2013/0507

Alves Junior, F. T., Ferreira, R. L. C., Silva, J. A. A., Marangon, L. C., \& Cespedes, G. H. G. (2013). Regeneração natural em de uma área de caatinga no sertão Pernambucano, nordeste do Brasil. Cerne, 19(2), 229-235. https://doi.org/10.1590/S0104-77602013000200006

Alves, L. S., Holanda, A. C., Wanderley, J. A., Souza, J. S., \& Almeida, P. G. (2010). Regeneração Natural em uma área de Caatinga situada no Município de Bombal-PB-Brasil. Revista Verde, 5(2), 152-168.

Andrade-Lima, D. (1981). The Caatinga Dominium. Revista Brasileira Botânica, 4(2), 149-153.

APG III. (2009). An Update of the Angiosperm Phylogeny Group Classification for the Orders and Families of Flowering Plants: Apg III. Botanical Journal of the Linnean Society, 161, 105-121. https://doi.org/10.1111/ j.1095-8339.2009.00996.x

Ferraz, J. S. F., Ferreira, R. L. C., Silva, J. A. A., Meunier, I. M. J., \& Santos, M. V. F. (2014). Estrutura do componente arbustivo-arbóreo da vegetação em duas áreas de caatinga, no município de floresta, Pernambuco. Revista Árvore, 38(6), 1055-1064. https://doi.org/10.1590/S0100-67622014000600010

Flora Do Brasil. (2017). Lista De Espécies Da Flora Do Brasil. Jardim Botânico do Rio de Janeiro.

Holanda, A. C., Lima, F. T. D., Silva, B. M., Dourado, R. G., \& Alves, A. R. (2015). Estrutura da Vegetação em Remanescentes de Caatinga com Diferentes Históricos de Perturbação em Cajazeirinhas (Pb). Revista Caatinga, 28(4), 142-150. https://doi.org/10.1590/1983-21252015v28n416rc

Jacomine, P. K. T. (1972). Levantamento Exploratório-Reconhecimento de Solos do Estado da Paraíba. Ministério da Agricultura (EPFS)/SUDENE (DRN). Rio de Janeiro.

Lucena, M. S., Alves, A. R., \& Bakke, I. A. (2017). Regeneração natural da vegetação arbóreo-arbustiva de Caatinga em face de duas formas de uso. Agropecuária Científica no Semiárido, 13(3), 212-222.

Lucena, M. S., Silva, J. A., \& Alves, A. R. (2016). Regeneração natural do estrato arbustivo-arbóreo em área de Caatinga na Estação Ecológica do Seridó-RN, Brasil. Revista Biotemas, 29(2), 17-31. https://doi.org/ 10.5007/2175-7925.2016v29n2p17

Lucena, M. S., Silva, J. A., \& Alves, A. R. (2018). Estrato regenerante do componente lenhoso em area de caatinga com diferentes usos, no serido potiguar. Revista de Ciências Ambientais, 12(1), 45-59. https://doi.org/10.18316/rca.v12i1.3496

Marangon, G. P., Ferreira, R. L. C., Silva, J. A. A., Lira, D. F. S. S., Silva, E. A., \& Loureiro, G. H. (2013). Estrutura e padrão espacial da vegetação em uma área de caatinga. Revista Floresta, 43(1), 83-92. https://doi.org/10.5380/rf.v43i1.27807

Marinho, F. P., Mazzochini, G. G., Manhãs, A. P., Weisser, W. W., \& Ganade, G. (2016). Effects of past and present land use on vegetation cover and regeneration in a tropical dryland forest. Journal of Arid Environments, 132, 26-33. https://doi.org/10.1016/j.jaridenv.2016.04.006

Mascarenhas, J. C., Beltrão, B. A, Souza, L. C. J, Morais F., Mendes, V. A., \& Miranda, J. L. F. (2005). CPRM Serviço Geológico do Brasil Projeto cadastro de fontes de abastecimento por água subterrânea. Diagnóstico do município de Cuité, estado da Paraíba. Recife: CPRM/PRODEEM.

Nativa, M. (2011). Sistema para análise itossociológica e elaboração de inventários e planos de manejo de florestas nativas (Manual do Usuário). Viçosa: Cientec.

Pereira, I. M., Andrade, L. A., Andrade, L. A, Costa, J. R. M., \& Dias, J. M. (2001). Regeneração natural em um remanescente de Caatinga sob diferentes níveis de perturbação, no agreste paraibano. Acta Botânica Brasílica, 15(3), 413-426. https://doi.org/10.1590/S0102-33062001000300010

Rêgo, P. L. (2008). Regeneração natural em matas ciliares na bacia do Rio Goiana-PE (Dissertação de Mestrado em Ciências Florestais, Universidade Federal Rural de Pernambuco, Recife). 
Rodal, M. J. N., Martins, F. R., \& Sampaio, E. V. S. B. (2008). Levantamento quantitativo das plantas lenhosas em trechos de vegetação de caatinga em Pernambuco. Revista Caatinga, 21(3), 192-205.

Sabino, F. G. S., Cunha, M. C. L., \& Santana, G. M. (2016). Estrutura da Vegetação em Dois Fragmentos de Caatinga Antropizada na Paraíba. Floresta e Ambiente, 14(1), 26-37. https://doi.org/10.1590/2179-8087. 017315

Sampaio, E. V. S. B., Araújo, E. L., Salcedo, I. H., \& Tifssfn, H. (1998). Regeneração da vegetação de caatinga após corte e queima em Serra Talhada, PE. Pesquisa Agropecuária Brasileira, 33(5), 621-632.

Santos, H. G., Jacomine, P. K. T., Anjos, L. H. C., Oliveira, V. A., Lumbreras, J. F., Coelho, M. R., ... Oliveira, J. B. (2013). Sistema brasileiro de classificação de solos (3rd ed.). Brasília, DF: Embrapa.

Santos, W. S., Souza, M. P., Nóbrega, G. F. Q., Medeiros, F. S., Alves, A. R., \& Holanda, A. C. (2017). Caracterização florístico-fitossociológica do componente lenhoso em fragmento de caatinga no município de Upanema-RN. Nativa, 5(2), 85-91. https://doi.org/10.5935/2318-7670.v05n02a02

Scolforo, J. R., \& Carvalho, L.M. (2008). Zoneamento ecológico-econômico do estado de Minas Gerais. UFLA, Lavras.

Silva, F. A. C. (2016). The Assistat Software Version 7.7 and its use in the analysis of experimental data. Afr. $J$. Agric. Res, 11(39), 3733-3740. https://doi.org/10.5897/AJAR2016.11522

Silva, J. A. (1994). Avaliação do Estoque Lenhoso-Inventário Florestal do Estado da Paraíba (Documento de Campo No. 21). João Pessoa: PNUD/FAO/IBAMA/GOVERNO DA PARAÍBA.

Silva, S. O., Ferreira, R. L. C., Silva, J. A. A., Lira, M. A., Alves Junior, F. T., Cano, M. O., \& Torres, J. E. L. (2012). Regeneração Natural em um remanescente de Caatinga com diferentes hitóricos de uso no Agreste pernambucano. Revista Árvore, 36(3), 441-450. https://doi.org/10.1590/S0100-67622012000300006

Silva, W. C., Marangon, L. C., Ferreira, R. L. C., Feliciano, A. L. P., \& Junior, R. F. C. (2007). Estudos da Regeneração Natural de Eespécies arbóres em fragmento Floresta Ombrófila densa, Mata das galinhas, no Município de Catende, Zona da Mata Sul de Pernambuco. Ciência Florestal, 17(4), 321-331. https://doi.org/10.5902/198050981964

SUDEMA (Superintendência de Administração do Meio Ambiente). (2004). Atualização do diagnóstico florestal do Estado da Paraíba. João Pessoa: SUDEMA.

\section{Copyrights}

Copyright for this article is retained by the author(s), with first publication rights granted to the journal.

This is an open-access article distributed under the terms and conditions of the Creative Commons Attribution license (http://creativecommons.org/licenses/by/4.0/). 